\title{
Growth and production of cholesterol oxidase by alginate- immobilized cells of Rhodococcus equi No. 23
}

\author{
Yu-Chih Chang and Cheng-Chun Chou' \\ Graduate Institute of Food Science and Technology, National Taiwan University, Taipei, Taiwan
}

\begin{abstract}
Rhodococcus equi No. 23 was immobilized in calcium alginate. No detrimental effect on the viability of the test organism was observed during the immobilization procedure. Approx. $98 \%$ of the cell population originally present in the alginate solution were immobilized in the gel beads. When the cells of an equal volume of the culture, obtained respectively at exponential phase (1 $2 \mathrm{~h}$ preculture), late-exponential phase ( $20 \mathrm{~h}$ preculture) or stationary phase ( $36 \mathrm{~h}$ preculture) were immobilized, the gel beads prepared with the stationary-phase culture were found to contain the highest cell population [about $10^{8}$ colony-forming units (CFU)/g of beads]. In addition, gel beads, prepared with late-exponential-phase culture, exhibited the highest production of cholesterol oxidase (CholOx) after $48 \mathrm{~h}$ of incubation. Increasing the bead mass from 3.5 to $14.0 \mathrm{~g} / 100 \mathrm{ml}$ of medium increased CholOx production. However, further increasing the bead mass resulted in a reduction of CholOx production. Furthermore, on the basis of a similar initial cell population, the alginateimmobilized cells of $R$. equi No. 23 produced a significantly higher amount of CholOx $(P<0.05)$ than did the free cells.
\end{abstract}

\section{Introduction}

Rhodococcus equi No. 23, first isolated by Watanabe et al. [1], is regarded as a potentially useful strain for the production of cholesterol oxidase (CholOx) [1-4]. CholOx catalyses the conversion of cholesterol into 4-cholesten-3-one. It has been used for the determination of cholesterol in blood serum and in the production of a starting material for the chemical synthesis of pharmaceutical steroids [I]. In addition, various investigators, on the basis of results obtained at laboratory level, indicated that use of CholOx may provide an economic and practical method for lowering the level of dietary cholesterol [5-7], which is partially related to cardiovascular disease, and hence serves to improve human health [8].

The use of immobilized microbial cells to carry out biotransformation or biosynthesis, and to improve fermentation processes, has been one of the most interesting techniques and has been extensively investigated [9]. In comparison with free suspended cells, immobilized cells exhibit tolerance to toxic substances [10], enhance fermentation productivity [ $\mathrm{I} \mathrm{I}$ ], can adapt to a wide range of $\mathrm{pH}$ environments [12] and high process temperature $[13,14]$ and are re-usable $[15,16]$.

In the present study we compared the growth and CholOx production by alginate-immobilized and free cells of $R$. equi No. 23 as influenced by the preculture time and inoculation size. Furthermore, the behaviour of $R$. equi No. 23 during the immobilization process with alginate was also examined.

\section{Materials and methods}

\section{Micro-organism}

R. equi No. 23 C.C.R.C. 13634 obtained from the Culture Collection and Research Center of the Food Industry Research and Development Institute (Hsinchu, Taiwan) was used in the present study and was maintained on nutrient agar (NA; Difco, Detroit, MI, USA) at $4{ }^{\circ} \mathrm{C}$. Before experimentation, the stock culture was activated by two successive transfers of the stock culture on nutrient broth (NB; Difco) supplemented with $0.5 \%$ yeast extract (Difco) at $37^{\circ} \mathrm{C}$ for $48 \mathrm{~h}$.

\section{Culture conditions}

For preculture and CholOx production, the culture medium described by Lee et al. [10] was used, consisting of $2.0 \mathrm{~g} / \mathrm{I}$ cholesterol, $8.0 \mathrm{~g} / \mathrm{l}$ yeast extract, $1.0 \mathrm{~g} / \mathrm{I} \mathrm{NaCl}, 1.0 \mathrm{~g} / \mathrm{I}$ $\mathrm{NH}_{4} \mathrm{Cl}, 0.5 \mathrm{~g} / \mathrm{I} \mathrm{KH}_{2} \mathrm{PO}_{4}, 0.25 \mathrm{~g} / \mathrm{I} \mathrm{Na}_{2} \mathrm{HPO}_{4}, 0.10 \mathrm{~g} / \mathrm{l} \mathrm{L}$-valine, $0.15 \mathrm{~g} / \mathrm{l} \quad$ L-tyrosine, $\quad 0.15 \mathrm{~g} / \mathrm{l} \quad \mathrm{MgSO}_{4}, \mathrm{H}_{2} \mathrm{O}, \quad 0.0 \mathrm{l} \quad \mathrm{g} / \mathrm{l}$ $\mathrm{ZnSO}_{4}, 7 \mathrm{H}_{2} \mathrm{O}, 0.10 \mathrm{~g} / \mathrm{I} \mathrm{FeSO}_{4}, 7 \mathrm{H}_{2} \mathrm{O}$ and $4.0 \mathrm{ml} / \mathrm{I}$ Tween 80 , $\mathrm{pH}$ 6.2.

The preculture for the immobilization experiment was prepared by transferring $1.0 \mathrm{ml}$ of the activated culture to $100 \mathrm{ml}$ of culture medium in a $250-\mathrm{ml}$ screw-capped Erlenmeyer flask with shaking at $150 \mathrm{rev} . / \mathrm{min}$ and at $37^{\circ} \mathrm{C}$ for various cultivation periods ( $12-36 \mathrm{~h}$ ). To study CholOx production, appropriate amounts of immobilized cells (gel

Key words: alginate gel bead, inoculum size, preculture time, survival.

Abbreviations used: CholOx, cholesterol oxidase; NA, nutrient agar; NB, nutrient broth.

Present address and address for correspondence: Graduate Institute of Food Science and Technology, National Taiwan University, 59 Lane 144, Keelung Rd., Sec. 4, Taipei, Taiwan (e-mail fstcchou@ccms.ntu.edu.tw). 
beads) or free cells of $R$. equi No. 23 as specified in the Results and discussion section, was inoculated into the medium in a $250-\mathrm{ml}$ screw-capped Erlenmyer flask at $37^{\circ} \mathrm{C}$ with shaking at $150 \mathrm{rev}$. $/ \mathrm{min}$ for a period of $48 \mathrm{~h}$.

\section{Immobilization of cells}

To immobilize $R$. equi No. 23, the method described by Lee et al. [10] was adopted with minor modifications. A $3 \%$ $(w / v)$ sodium alginate solution was first prepared by dissolving an appropriate amount of sodium alginate in a $0.9 \% \mathrm{NaCl}$ solution, then autoclaving and cooling it to room temperature. The precultured cells were then mixed with the alginate solution at a ratio of $\mathrm{I}: 6(\mathrm{v} / \mathrm{v})$. The mixture was then added dropwise to a gently stirred $3 \% \mathrm{CaCl}_{2}$ solution by means of a peristaltic pump (Minipuls model 312, Gibson, Villiers Le Bel, France) fitted with a silicon glass tube that had a tip. The resulting calcium alginate beads, with a diameter of about $2.2 \mathrm{~mm}$, were incubated in a $\mathrm{CaCl}_{2}$ solution for $\mathrm{I} \mathrm{h}$. These beads were then washed three times with sterile water.

\section{Electron microscopy}

Electron microscopy, as described by Fukushima et al. [17], was used to observe the alginate gel beads with or without $R$. equi No. 23. Gel beads were first cut into halves with a razor. Half pieces of the gel bead were then fixed with $2.5 \%$ glutaraldehyde in $0.1 \mathrm{M}$ Tris $/ \mathrm{HCl}$ buffer, $\mathrm{pH} 7.0$, at $5{ }^{\circ} \mathrm{C}$ for I h, washed with $0.1 \mathrm{M}$ Tris $/ \mathrm{HCl}$ buffer, $\mathrm{pH} 7.0$, containing $5 \%$ sucrose, and treated with $1 \%$ osmium textroxide in

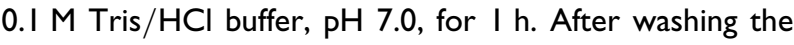
resultant osmium-treated half-bead with $0.1 \mathrm{M}$ Tris $/ \mathrm{HCl}$ buffer, $\mathrm{pH} 7.0$, dehydration was achieved by successive extraction with $50,60,70,80,90,95$, and $99.5 \%$ ethanol and finally with acetone over a period of $15 \mathrm{~min}$. Finally these beads were dried using the $\mathrm{CO}_{2}$ critical-point drying technique and coated with gold for examination by scanning electron microscopy.

\section{Analytical methods}

The cell population of $R$. equi No. 23 in media was measured by counting the number of viable cells after surface plating on $\mathrm{NA}$ and incubation at $37^{\circ} \mathrm{C}$ for 3 days. Immobilized cells in the alginate beads were counted after dissolution of the beads in $0.2 \mathrm{M}$ citrate buffer ( $\mathrm{pH}$ 5.0). In the present study, extracellular CholOx production was determined. Culture broth was centrifuged at $5600 \mathrm{~g}\left(5^{\circ} \mathrm{C}\right)$ for $15 \mathrm{~min}$ and the supernatant was used as the enzyme source. Assay of CholOx activity was based on the conversion of cholesterol into 4-cholesten-3-one as described by Shirokane et al. [18]. One unit of CholOx is defined as the amount of enzyme required to form I $\mu \mathrm{mol}$ of 4 -cholesten-3-one/min under the test condition.

\section{Statistical analysis}

Each experiment was conducted at least in triplicate. The mean values and the S.D. were calculated with the data obtained from these trials. These data were then compared using Duncan's multiple range method [19].

\section{Results and discussion}

\section{Survival of $R$. equi No. 23 during the immobilization process}

Among alternative processes for immobilization, entrapment of microbial cells in a polysaccharide gel such as kcarrangenans or calcium alginate is one of the most commonly used procedures [20]. However, cell viability can be altered during the immobilization process [I6,2I]. To examine the survival of $R$. equi No. 23 during the immobilization with alginate, the viable population of test organism was determined after each step in the immobilization procedure. A viable population of 7.8 log colony-forming units (CFU) $/ \mathrm{ml}$ was found when determined immediately after suspension in sodium alginate solution. It is similar to that (7.8 log CFU/ml) determined after suspension in water, which served as the control. This indicates that the alginate did not cause any detrimental effect on the viability of test

(A)

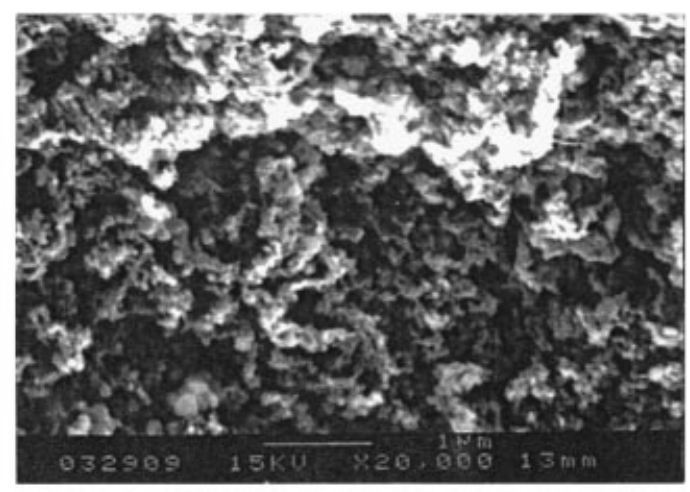

(B)

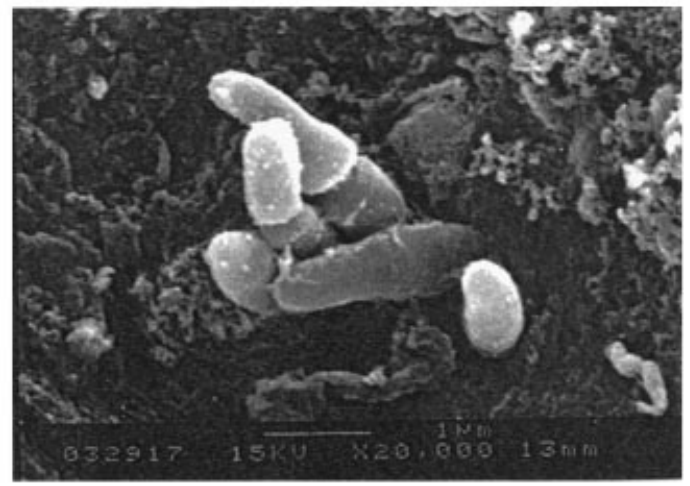

Figure I Scanning electronmicrograph of a calcium alginate bead $(\mathbf{A})$ and a calcium alginate bead entrapped with $R$. equi No. 23 (B) 


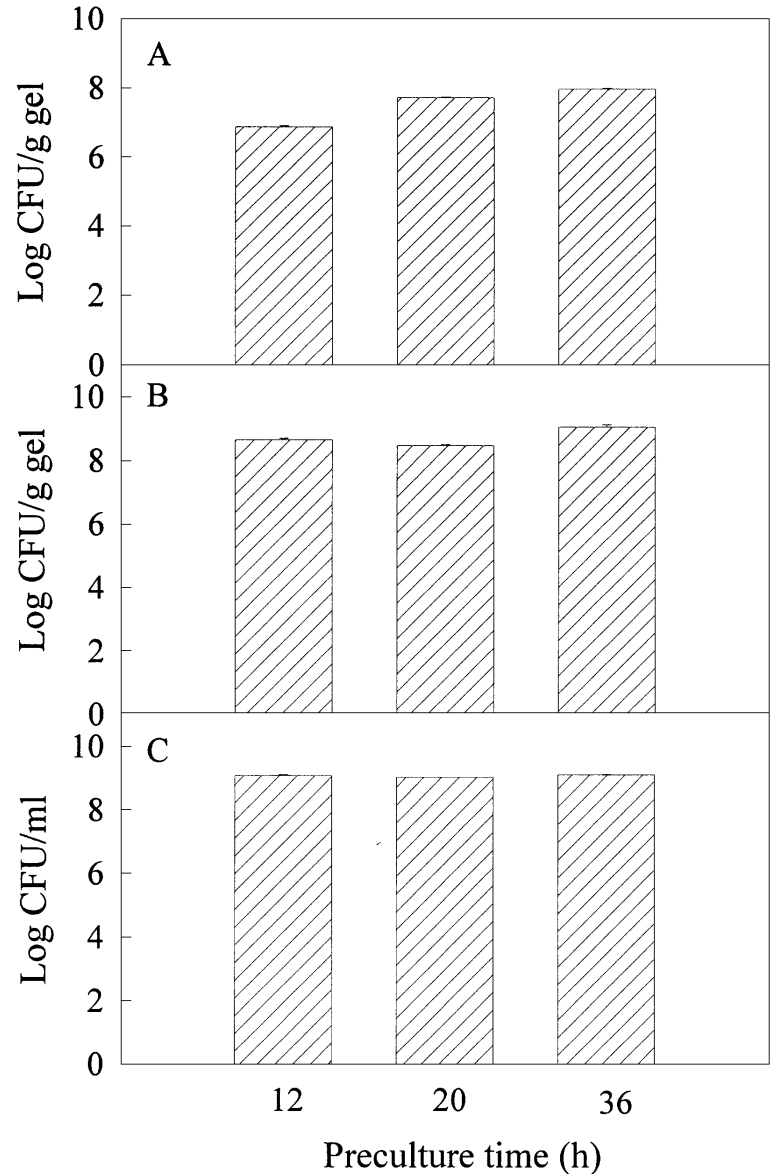

Figure 2 Effect of preculture time on the growth of immobilized $R$. equi No. 23

(A) Viable immobilized cells inside calcium alginate beads determined immediately after inoculation; (B) inside calcium alginate beads; (C) outside calcium alginate beads after $48 \mathrm{~h}$ of cultivation.

organism during the immobilization process. In addition, it was noted that about $98 \%$ of the cell population originally present in the alginate solution was immobilized in the gel beads, which contained a viable population of about $7.4 \mathrm{log}$ $\mathrm{CFU} / \mathrm{g}$.

Figure I shows the scanning electron micrograph of the calcium alginate bead with or without the entrapped cells R. equi No. 23.

\section{Effect of preculture time}

To examine the effect of preculture time on the immobilization of $R$. equi No. 23 and CholOx production, various cultures was obtained after growth of the organism for 12, 20 and $36 \mathrm{~h}$, corresponding to exponential phase, late-exponential phase and stationary phase respectively. Cells from an equal volume of the culture were then immobilized within calcium alginate beads and $7.0 \mathrm{~g}$ of beads was inoculated into the media. Similar to the observation of Lee et al. [16], who investigated the production of

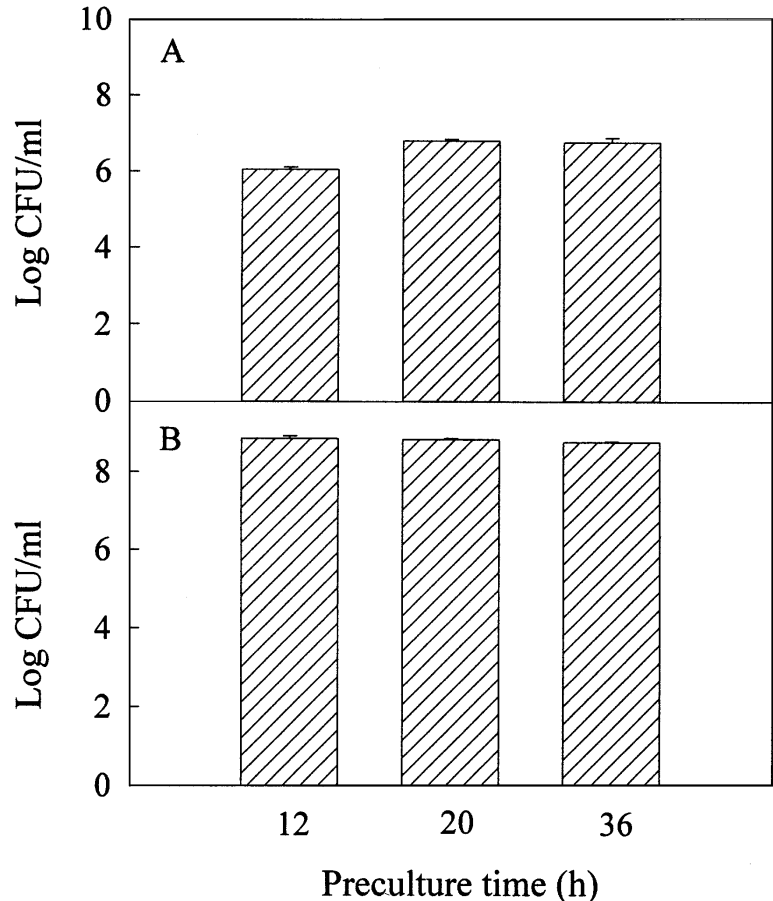

Figure 3 Effect of preculture time on the growth of non-immobilized R. equi No. 23

(A) Initial population of viable cells; (B) population of viable cells after $48 \mathrm{~h}$ of cultivation

$\gamma$-decalactone by immobilized cells of Sporidiobolus salmonicolor, it was noted that the longer the preculture time, the greater the population of $R$. equi No. 23 inside the bead (Figure 2). Gel beads prepared with $36 \mathrm{~h}$ of preculture contained the highest population of test organism (about $8.0 \mathrm{log}$ $\mathrm{CFU} / \mathrm{g}$ of gel), whereas gel beads prepared with $12 \mathrm{~h}$ preculture contained the lowest population (about $6.9 \mathrm{log}$ $\mathrm{CFU} / \mathrm{g}$ of gel). The difference in initial cell level found inside gel beads may be attributed to the higher number of cells in culture with longer preculture time. A population of viable cells, ranging between 8.7 and $9.1 \log C F U / g$ of gel within the gel beads, was observed after $48 \mathrm{~h}$ of cultivation (Figure 2B). On the other hand, the final cell level of viable $R$. equi No. 23 outside the beads was more than $9.0 \log \mathrm{CFU} / \mathrm{ml}$, regardless of the preculture time or initial number of cells entrapped in the gel beads (Figure 2C).

For comparison, we also examined the growth and CholOx production by free cells. The precultures stopped at different cultivation times were used to innoculate $100 \mathrm{ml}$ portions of the medium, in a manner such as to start the cultures with the same initial cell concentrations as those of the cultures inoculated above with immobilized cells. As shown in Figure 3, the final population of viable free cells determined after $48 \mathrm{~h}$ of cultivation showed no significant difference $(P>0.05)$, regardless the preculture time of 


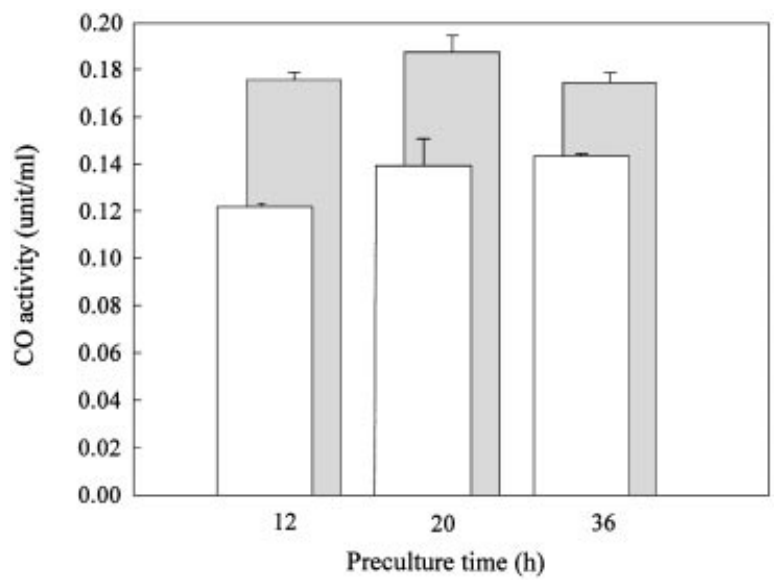

Figure 4 Effect of preculture time on the CholOx (' $\mathrm{CO}$ ') production by immobilized cells (圆) and non-immobilized cells ( $\square$ ) of R. equi No. 23 after $48 \mathrm{~h}$ of cultivation

inocula. However, it is noteworthy that the final cell number in the culture inoculated with non-immobilized $R$. equi No. 23 (Figure 3B) was generally lower than those free cells observed in the culture inoculated with immobilized cells (Figure 2C).

Figure 4 shows the CholOx production in cultures inoculated with immobilized or free cells of $R$. equi No. 23 prepared at different preculture times. Cultures inoculated with the $12 \mathrm{~h}$ preculture of immobilized or free cells had the lowest CholOx production. The low initial cell level in these cultures may be one of the reasons attributed to this observation. On the other hand, a medium inoculated with beads prepared with $20 \mathrm{~h}$ preculture cells contained a slightly lower initial population than that inoculated with beads prepared with $36 \mathrm{~h}$ preculture cells. In contrast, the former exhibited a significantly higher CholOx activity $(P<0.05)$ than the latter after $48 \mathrm{~h}$ of incubation. This clearly demonstrated that preculture time may affect the production of CholOx by the alginate-immobilized cells and free cells of $R$. equi No. 23.

When grown in a jar fermenter, we previously noted that $R$. equi No. 23 produced a maximum CholOx activity of $0.34 \mathrm{unit} / \mathrm{ml}$ in $30 \mathrm{~h}$ of cultivation at an aeration rate of $5.0 \mathrm{l} / \mathrm{min}$, if the $\mathrm{pH}$ of the culture medium, the cultivation temperature and the agitation speed were controlled at 6.5 , $39{ }^{\circ} \mathrm{C}$ and $200 \mathrm{rev}$./min respectively during the first $24 \mathrm{~h}$ of cultivation, then shifted to $7.5,37^{\circ} \mathrm{C}$ and $300 \mathrm{rev} . / \mathrm{min}$ respectively [4]. Considering the main object of the present study, growth and CholOx production, were simply tested by growing the free or immobilized cells of $R$. equi No. 23 in an Erlenmeyer flask at $37^{\circ} \mathrm{C}$ with shaking at $150 \mathrm{rev} . / \mathrm{min}$ for $48 \mathrm{~h}$ without changing the cultivation condition during the fermentation period. As shown in Figure 4 the level of CholOx produced by immobilized $R$. equi No. 23, although

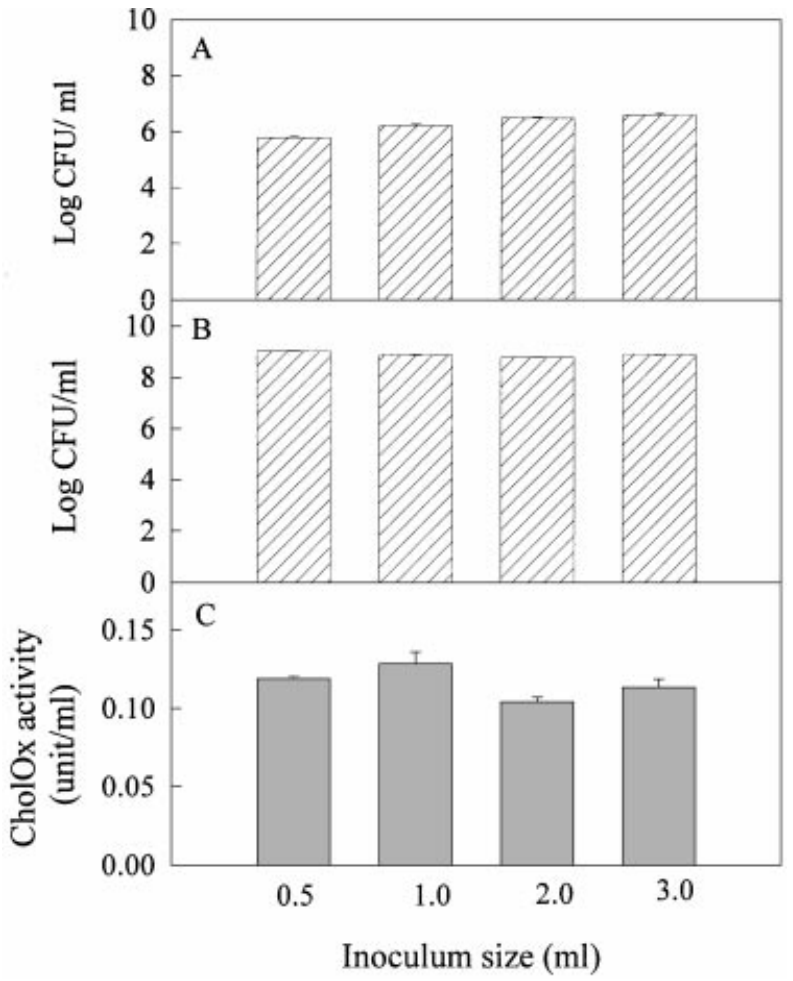

Figure 5 Effect of inoculum size on the growth and CholOx production by non-immobilized $R$. equi No. 23

(A) Viable cells determined immediately after inoculation; (B) opulation of viable cells; and $(\mathbf{C})$ CholOx activity after $48 \mathrm{~h}$ of cultivation.

lower than that reported by Chou et al. [4], was significantly higher $(P<0.05)$ than that produced by its respective free cells under similar test conditions. This observation is different from the reports of Kanasawud et al. [22] and Manolov et al. [23]. Kanasawud et al. [22] observed a decreased production of protease by alginate-immobilized cells of Thermus aquaticus, while Manolov et al. [23] reported a reduced pullulanase production by Bacillus stearothermophilus due to the negative effect of $\mathrm{Ca}^{2+}$ ions on enzyme activity. During the cultivation of immobilized cells, cells are released from the gel beads. Mori et al. [24] indicated that newly released cells from gel beads have a higher specific growth rate and metabolic rate than nonimmobilized cells. This may account for the higher final population and CholOx production in cultures with immobilized cells than with non-immobilized cells, as observed in the present study.

\section{Effect of inoculum size}

Various investigators have reported that enzyme and metabolite levels produced by immobilized cells, were affected by inoculum size $[11,16,25,26]$. Production of CholOx by free 


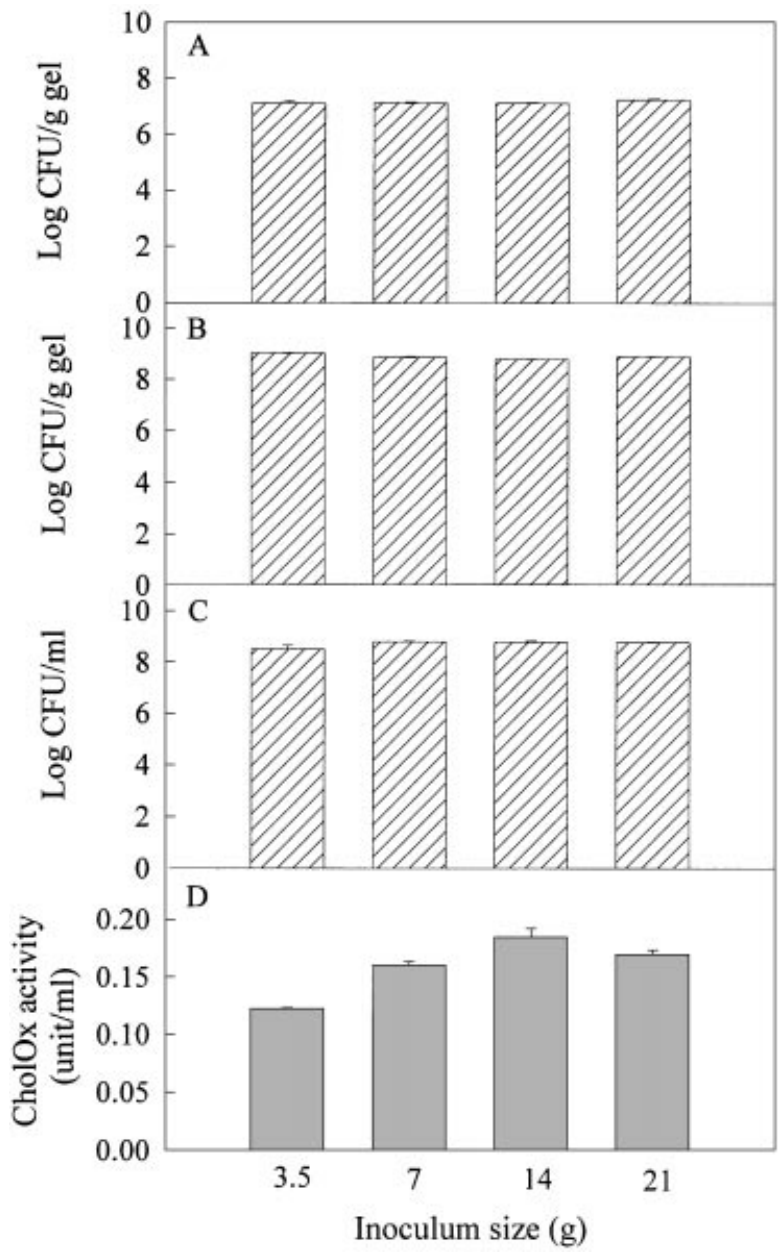

Figure 6 Effect of inoculum size on the growth and CholOx production by immobilized $R$. equi No. 23

(A) Viable cells inside gel beads determined immediately after inoculation; (B) population of viable cells inside gel beads; (C) population of free cells in culture; and (D) cholOx activity after $48 \mathrm{~h}$ of cultivation.

and immobilized cells of $R$. equi No. 23 after $48 \mathrm{~h}$ of cultivation are shown in Figures 5 and 6 respectively. Production of CholOx was not proportional with the inoculum size of the free cells present in the media (Figure 5). Among the various inoculum sizes tested, the culture with an inoculum size of $1.0 \mathrm{ml}$, having viable population $R$. equi No. 23 similar to that in $7.0 \mathrm{~g}$ of gel beads, exhibited the highest CholOx production of about $0.13 \mathrm{unit} / \mathrm{ml}$ after $48 \mathrm{~h}$ of cultivation. In contrast, culture inoculated with $2.0 \mathrm{ml}$ of inoculum showed the lowest CholOx production, only 0.10 unit $/ \mathrm{ml}$. On the other hand, the final population of test organism in the cultures with different initial inoculation sizes did not show significant difference after $48 \mathrm{~h}$ of cultivation (Figure 5B).

As shown in Figure 6, the population of free cells in cultures inoculated with various quantities of gel beads ranged from 8.5 to $8.8 \log \mathrm{CFU} / \mathrm{ml}$ after $48 \mathrm{~h}$ of cultivation and showed no significant difference $(P>0.05)$ among them (Figure 6C). An increase in the production of CholOx was noted as the quantity of gel beads increased from 3.5 to 14.0 g per $100 \mathrm{ml}$ of medium (Figure 6D). Further increasing the quantity of gel beads resulted in the reduction in CholOx production. In the culture inoculated with $14.0 \mathrm{~g}$ of gel beads / $100 \mathrm{ml}$ of medium, the highest CholOx production of about $0.18 \mathrm{unit} / \mathrm{ml}$ was obtained, whereas CholOx production in the culture inoculated with $3.5 \mathrm{~g}$ of gel beads/ $100 \mathrm{ml}$ of medium was lowest with only 0.12 unit $/ \mathrm{ml}$. Furthermore, on the basis of comparable cell populations, the CholOx production in culture with immobilized $R$. equi No. 23 (Figure 6D) was found to be significantly higher than with the corresponding free cells (Figure $5 \mathrm{C}$ ). The failure to increase CholOx production with an increasing quantity of gel beads, as noted in the present study, has also been observed by previous investigators [ I I, I6,26]. Among these, Kim and Chang [I I] produced shikonin with calcium alginateimmobilized cells of Lythospermum erythrorhizon. They indicated that lower cellular metabolic activity was caused by nutrient deficiency, which occurred in cultures with higher bead concentrations and thus resulted in low shikonin production. In addition, Slokoska et al. [26] studied the acid proteinase production by Humicola luted $120-5$ immobilized in gel beads and found a larger gel inoculum leading to a decrease of enzyme production. They attributed this phenomenon to the decreased nutrient beads ratio at higher gel inoculum, as previously indicated by Vuillemard et al. [27].

\section{Conclusion}

On the basis of data obtained in the present study, it can be concluded that immobilization with alginate has no detrimental effect on cells of $R$. equi No. 23 or on CholOx production. Cultivation of immobilized cells prepared with $20 \mathrm{~h}$ preculture time and with a gel bead quantity of $14.0 \mathrm{~g} / 100 \mathrm{ml}$ of medium resulted in the highest production of CholOx. Furthermore, cultivation with alginateimmobilized $R$. equi No. 23 led to a higher CholOx production than with free cells.

\section{Acknowledgement}

This work was supported by the National Science Council (NSC 89-23 I3-B-002-08I), Taiwan.

\section{References}

I Watanabe, K., Shimizu, H., Aihara, H., Nakamura, R. and Suzuki, K. I. (1986) J. Gen. Appl. Microbiol. 32, I37-147 
2 Watanabe, K., Aihara, H., Nakagawa, Y., Nakamura, R. and Sasaki, T. (1989) J. Agric. Food Chem. 37, I 178-I I 82

3 Lee, M. T., Chen, W. C. and Chou, C. C. (1997) Process Biochem. 32, 697-703

4 Chou, C. C., Lee, M. T. and Chen, W. C. (1999) Biotechnol. Appl. Biochem. 29, 217-221

5 Aihara, H., Watanabe, K. and Nakamura, R. (1988) J. Food Sci. 53, 659-660

6 Watanabe, K., Aihara, H. and Nakamura, R. (1989) Lebensm. Wiss. Technol. 22, 98-99

7 Christodoulou, S., Hung, T. V., Trewhell, M. A. and Black, R. G. (1994) J. Food Prot. 57, 908-912

8 Kaunitz, H. (1978) Lipids 13, 373-374

9 Dervakos, G. A. and Webb, C. (1991) Biotech. Adv. 9, 559-612

10 Lee, S. L., Cheng, H. Y., Chen, W. C. and Chou, C. C. (1998) Process Biochem. 33, 453-459

II Kim, D. J. and Chang, H. N. (1990) Biotechnol. Bioeng. 36, 460-466

12 Buzás, Z. S., Dallmann, K. and Szajáni, B. (1989) Biotechnol. Bioeng. 34, 882-884

13 Bajpai, P. and Margaritis, A. (1987) Biotechnol. Bioeng. 30, 306-313

I4 Tan, Q. and Day, D. F. (1998) Appl. Microbiol. Biotechnol. 49, 96-10।

15 Paik, H. D. and Glatz, B. A. (1994) Appl. Microbiol. Biotechnol. 42, 22-27
16 Lee, S. L., Cheng, H. Y., Chen, W. C. and Chou, C. C. (1999) Process Biochem. 34, 845-850

17 Fukushima, Y., Okamura, K., Imai, K. and Motai, H. (1988) Biotechnol. Bioeng. 32, 584-594

I8 Shirokane, Y., Nakamura, K. and Mizusawa, K. (1977) J. Ferment Technol. 55, 337-346

19 SAS (1989) SAS User's Guide: Statistics (Version 6 edn), SAS Institute Inc., Cary NC

20 Gerbsch, N. and Buchholz, R. (1995) FEMS Microbiol. Rev. 16, 259-269

21 Groboillot, A., Boadi, D. K., Poncelet, D. and Neufeld, R. J. (1994) Crit. Rev. Biotechnol. 14, 75-107

22 Kanasawud, P., Hjorleifsdottir, S., Holst, O. and Mattiasson, B. ( 1989) Appl. Microbiol. Biotechnol. 31, 228-233

23 Manolov, R. J., Kambourova, M. S. and Emanuilova, E. I. (1995) Proc. Biochem. 30, |4|-| 44

24 Mori, A., Matsumoto, N. and Imai, C. (1989) Biotechnol. Lett. II, 183-188

25 El-Aassar, S. A., El-Badry, H. M. and Abdel-Fattah, A. F. (1990) Appl. Microbiol. Biotechnol. 33, 26-30

26 Slokoska, L., Angelova, M., Pashova, S., Petricheva, E. and Konstantinov, C. H. (1999) Process Biochem. 34, 73-76

27 Vuillemard, I., Terre, S., Benoit, S. and Amiot, J. (1988) Appl. Microbiol. Biotechnol. 27, 523-438

Received 26 July 2001/5 November 2001; accepted 3 December 2001 